\title{
Hymenobacter yonginensis sp. nov., isolated from a mesotrophic artificial lake
}

\author{
Yochan Joung, ${ }^{1}$ Sung-Heun $\mathrm{Cho}^{2}{ }^{\text {Haneul Kim, }}{ }^{1}$ Seung Bum Kim ${ }^{2}$ \\ and Kiseong Joh ${ }^{1}$ \\ ${ }^{1}$ Department of Bioscience and Biotechnology, Hankuk University of Foreign Studies, Wangsan, \\ Yongin, Gyeonggi 449-791, Republic of Korea \\ ${ }^{2}$ Department of Microbiology, School of Bioscience and Biotechnology, Chungnam National \\ University, 220 Gung-dong, Yuseong, Daejeon 305-764, Republic of Korea
}

Correspondence

Kiseong Joh

ksjoh@hufs.ac.kr

\begin{abstract}
A non-motile, red-pigmented bacterium, designated strain $\mathrm{HMD} 1010^{\top}$, was isolated from an artificial lake located within the campus of Hankuk University of Foreign Studies, Yongin, Korea. A phylogenetic tree based on $16 \mathrm{~S}$ rRNA gene sequences showed that strain $\mathrm{HMD} 1010^{\top}$ formed a lineage within the genus Hymenobacter and was closely related to the type strains of Hymenobacter rigui (96.7\% sequence similarity) and $H$. gelipurpurascens $(95.6 \%)$. The major fatty acids were $\mathrm{C}_{16: 1} \omega 5 c(21.9 \%)$, summed feature 3 (iso- $\mathrm{C}_{15: 0} 2-\mathrm{OH}$ and/or $\mathrm{C}_{16: 1} \omega 7 c$; $17.2 \%$ ), iso- $\mathrm{C}_{15: 0}\left(14.5 \%\right.$ ) and summed feature 4 (anteiso- $\mathrm{C}_{17: 1} \mathrm{~B}$ and/or iso- $\mathrm{C}_{17: 1} \mathrm{I} ; 11.9 \%$ ). The DNA G +C content was $60.4 \mathrm{~mol} \%$. On the basis of the evidence presented in this study, strain HMD1010 ${ }^{\top}$ represents a novel species of the genus Hymenobacter, for which the name Hymenobacter yonginensis sp. nov. was proposed. The type strain is $\mathrm{HMD} 1010^{\top}(=\mathrm{KCTC}$ $22745^{\top}=$ CECT $7546^{\top}$ ).
\end{abstract}

The genus Hymenobacter was described by Hirsch et al. (1998), and members of the genus have high DNA G $+\mathrm{C}$ contents (55-65 mol\%) compared with other members of the family Flexibacteraceae. At the time of writing, the genus Hymenobacter included 14 species: Hymenobacter roseosalivarius (the type species; Hirsch et al., 1998), $H$. actinosclerus (Collins et al., 2000), H. aerophilus (Buczolits et al., 2002), H. norwichensis, H. ocellatus, H. gelipurpurascens and $H$. chitinivorans (Buczolits et al., 2006), $H$. xinjiangensis (Zhang et al., 2007), H. soli (Kim et al., 2008), H. psychrotolerans (Zhang et al., 2008), H. deserti (Zhang et al., 2009), $H$. daecheongensis (Xu et al., 2009) and $H$. psychrophilus (Zhang et al., 2011). Members of the genus have been isolated from various environments including deserts (in China and Antarctica) and vegetated soils, sandstone and wetlands.

In the course of a study on the microbial diversity of a mesotrophic freshwater lake (surface water, $17^{\circ} \mathrm{C}$ ) within the campus of Hankuk University of Foreign Studies, Yongin, Republic of Korea, a strain forming red-pigmented colonies was isolated using the standard dilution plating technique. Strain HMD1010 ${ }^{\mathrm{T}}$ was incubated on R2A agar (Difco) for $24 \mathrm{~h}$ at $30{ }^{\circ} \mathrm{C}$. The isolate was routinely cultured on the same medium at $30{ }^{\circ} \mathrm{C}$ and the culture was suspended in aqueous glycerol $(20 \%, \mathrm{w} / \mathrm{v})$ for storage at $-80{ }^{\circ} \mathrm{C}$.

The GenBank/EMBL/DDBJ accession number for the 16S rRNA gene sequence of strain $\mathrm{HMD} 1010^{\top}$ is GU808562.
An almost-complete sequence of the 16S rRNA gene (1392 bp) was obtained for strain HMD $1010^{\mathrm{T}}$ as described previously (Cho \& Giovannoni, 2003). Identification of phylogenetic neighbours and calculation of pairwise 16S rRNA gene sequence similarity were performed by using the EzTaxon server (http://www.eztaxon.org/; Chun et al., 2007). Phylogenetic and molecular evolutionary analyses were conducted by using MEGA version 4 (Tamura et al., 2007). Sequence comparisons showed that strain HMD $1010^{\mathrm{T}}$ was closely related to members of the genus Hymenobacter. Phylogenetic trees were inferred using the maximum-likelihood (Felsenstein, 1981), maximumparsimony (Fitch, 1971) and neighbour-joining (Saitou \& Nei, 1987) algorithms. The robustness of the topologies for the maximum-likelihood and neighbour-joining trees was evaluated by means of bootstrap analysis (Felsenstein, 1985) based on 1000 resamplings of the sequences. The trees generated in this study (Fig. 1) indicated that strain HMD $1010^{\mathrm{T}}$ belonged to the genus Hymenobacter. Strain HMD $1010^{\mathrm{T}}$ formed a coherent clade with the type strains of $H$. rigui ( $96.2 \%$ similarity) and $H$. gelipurpurascens (95.6\%), within the phylogenetically well-resolved Hymenobacter clade. This phylogenetic inference, coupled with $16 \mathrm{~S}$ rRNA gene sequence similarities of $<97 \%$ (Wayne et al., 1987) between strain HMD $1010^{\mathrm{T}}$ and strains of other Hymenobacter species, suggested that the strain should be assigned to the genus Hymenobacter as a representative of a novel species. 


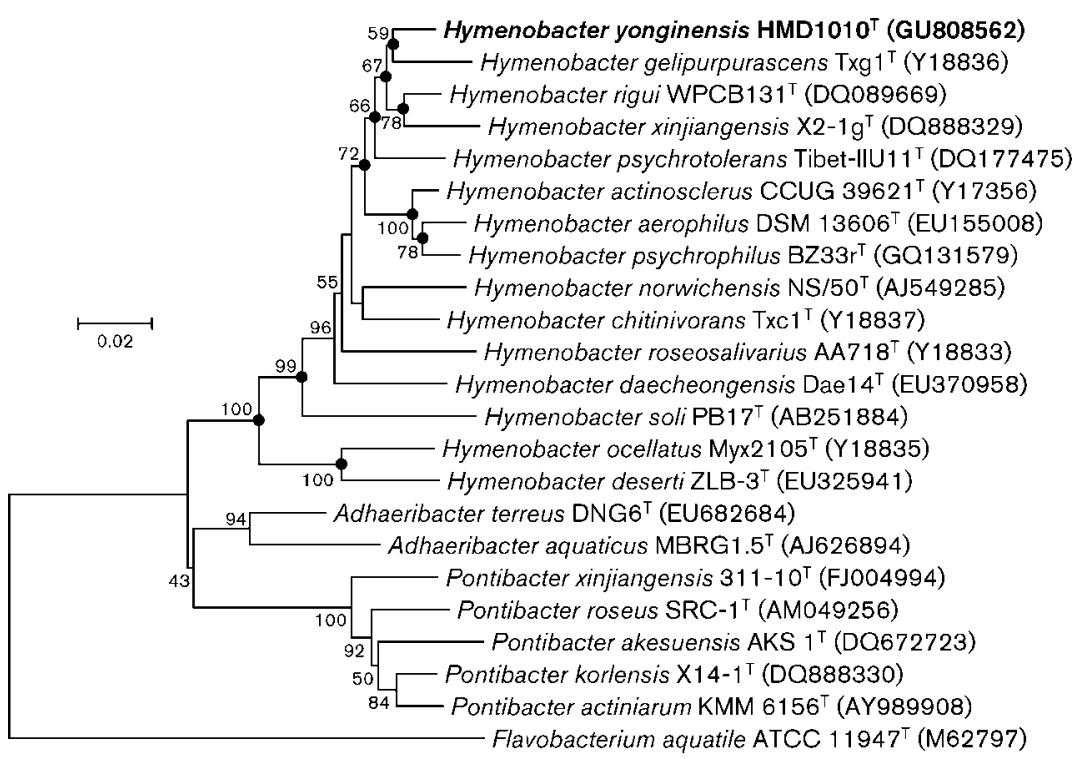

Fig. 1. Neighbour-joining phylogenetic tree based on nearly complete 16S rRNA gene sequences showing the relationships between strain $\mathrm{HMD} 1010^{\top}$ and strains of the genus Hymenobacter. Percentages at nodes are levels of bootstrap support $(>50 \%)$ based on neighbour-joining analyses of 1000 resampled datasets. Filled circles indicate nodes recovered by all three treeing methods. The sequence of Flavobacterium aquatile ATCC $11947^{\top}$ was used as the outgroup. Bar, 0.02 substitutions per nucleotide position.
Cell morphology was examined by light microscopy. Gram staining was determined using the bioMérieux Gram stain kit according to the manufacturer's instructions. Anaerobic growth was tested on $\mathrm{R} 2 \mathrm{~A}$ agar at $30{ }^{\circ} \mathrm{C}$ by using the GasPak EZ anaerobic container system (BD) according to the manufacturer's instructions. Cellular pigments were extracted with acetone/methanol $(1: 1, \mathrm{v} / \mathrm{v})$ and their absorption spectra were determined using a scanning UV/visible spectrophotometer (UV 6101A; Shimadzu). The presence of flexirubin-type pigments was investigated by using the bathochromatic shift test with $\mathrm{NaOH}$ solution (Bernardet et al., 2005). Catalase and oxidase tests were performed according to standard methods (MacFaddin, 1980). The $\mathrm{pH}$ range for growth was determined in R2A broth at $20{ }^{\circ} \mathrm{C}$. The medium was adjusted to $\mathrm{pH} 5.0-10.0$ (at intervals of $1.0 \mathrm{pH}$ unit) using $0.1 \mathrm{mM}$ sodium acetate buffer ( $\mathrm{pH} 5.0-7.0$ ), $0.1 \mathrm{mM}$ phosphate buffer ( $\mathrm{pH} 7.0-$ 8.0 ) and $0.1 \mathrm{mM}$ sodium carbonate buffer ( $\mathrm{pH} 9.0-10.0)$. Growth at various $\mathrm{NaCl}$ concentrations $[0.5 \%(\mathrm{w} / \mathrm{v})$ and $1.0-10.0 \%(\mathrm{w} / \mathrm{v})$ at intervals of $1.0 \%$ ] was investigated in modified R2A broth. The temperature range and optimum for growth were measured in $\mathrm{R} 2 \mathrm{~A}$ broth at $4-42{ }^{\circ} \mathrm{C}$ (at $4{ }^{\circ} \mathrm{C}, 10-30{ }^{\circ} \mathrm{C}$ at $5{ }^{\circ} \mathrm{C}$ intervals, 37 and $\left.42{ }^{\circ} \mathrm{C}\right)$. Hydrolysis of casein [3.0\%, v/v, skimmed milk (Difco)], CM-cellulose $[1.0 \%, \mathrm{w} / \mathrm{v}, \mathrm{CM}$-cellulose (Sigma)] and starch $(1.0 \%, \mathrm{w} / \mathrm{v})$ was tested using R2A agar as the basal medium. Growth was assessed on marine agar 2216 (MA), cetrimide agar, trypticase soy agar (TSA) and MacConkey agar (all from Difco). DNase test agar (Difco) was used to assess production of DNase. Basic biochemical tests, enzyme activity tests and carbon source oxidation tests were performed using API 20E and API ZYM strips (bioMérieux) and Biolog GN3 MicroPlates according to the manufacturers' instructions. The DNA G + C content was determined by using HPLC (Mesbah \& Whitman, 1989). For fatty acid methyl ester analysis, biomass of strain $\mathrm{HMD}_{1010^{\mathrm{T}}}$ and the reference strains $H$. aerophilus KACC $12071^{\mathrm{T}}, H$. gelipurpurascens KACC $12069^{\mathrm{T}}$, H. rigui KACC $11614^{\mathrm{T}}$ and H. psychrotolerans KACC $13767^{\mathrm{T}}$ was harvested from cells grown on R2A agar at $30{ }^{\circ} \mathrm{C}$ for $48 \mathrm{~h}$. Fatty acid methyl esters were extracted and prepared according to the standard protocol of the MIDI/Hewlett Packard Microbial Identification System.

Morphological, cultural, physiological and biochemical characteristics of strain HMD $1010^{T}$ are listed in Table 1 and in the species description. Cells of strain HMD $1010^{\mathrm{T}}$ were Gram-staining-negative, red-pigmented, strictly aerobic and non-motile. Strain HMD $1010^{\mathrm{T}}$ exhibited a number of phenotypic similarities to species of the genus Hymenobacter (Hirsch et al., 1998; Buczolits et al., 2006). However, test results for growth in $2 \% \mathrm{NaCl}$ concentration, growth at $\mathrm{pH} 8$ and utilization of D-mannitol clearly differentiated strain HMD $1010^{\mathrm{T}}$ from related Hymenobacter species (Table 1).

The fatty acid profile of strain HMD $1010^{\mathrm{T}}$ included the major components $\mathrm{C}_{16: 1} \omega 5 c(21.9 \%)$, summed feature 3 (iso- $\mathrm{C}_{15: 0} \quad 2-\mathrm{OH}$ and/or $\mathrm{C}_{16: 1} \omega 7 c ; 17.2 \%$ ), iso- $\mathrm{C}_{15: 0}$ $(14.5 \%)$ and summed feature 4 (anteiso- $\mathrm{C}_{17: 1} \mathrm{~B}$ and/or iso- $\mathrm{C}_{17: 1} \mathrm{I} ; 11.9 \%$ ) (Table 2 ). This fatty acid profile was similar to those of other Hymenobacter species, although there were differences in the proportions of some fatty acids, including summed feature 4 and summed feature 2 (iso- $\mathrm{C}_{16: 1} \mathrm{I}$ and/or $\mathrm{C}_{14: 0} 3-\mathrm{OH}$ ) (Table 2). The DNA G $+\mathrm{C}$ content of strain $\mathrm{HMD} 1010^{\mathrm{T}}$ was $60.4 \mathrm{~mol} \%$, a value within the range reported for members of the genus Hymenobacter (54-65 mol\%). Chemotaxonomic data confirm the phylogenetic affiliation of strain $\mathrm{HMD} 1010^{\mathrm{T}}$ as a member of the genus Hymenobacter. Therefore, strain HMD $1010^{\mathrm{T}}$ should be classified in the genus Hymenobacter as a member of a novel species, for which the name Hymenobacter yonginensis sp. nov. is proposed. 
Table 1. Differential characteristics of strain HMD $1010^{\top}$ and closely related type strains of genus Hymenobacter

Strains: 1, $\mathrm{HMD}_{1010^{\mathrm{T}}}$; 2, H. aerophilus KACC $12071^{\mathrm{T}}$; 3, H. gelipurpurascens KACC $12069^{\mathrm{T}}$; 4, H. rigui KACC $11614^{\mathrm{T}}$; $5, H$. psychrotolerans KACC $13767^{\mathrm{T}}$. Data were generated in this study except for the DNA $\mathrm{G}+\mathrm{C}$ contents of the four reference strains (data from Buczolits et al., 2002, 2006; Zhang et al., 2008; Baik et al., 2006). All strains were negative for utilization of L-histidine (Biolog GN3).

\begin{tabular}{|c|c|c|c|c|c|}
\hline Characteristic & 1 & 2 & 3 & 4 & 5 \\
\hline Growth at $\mathrm{pH} 8$ & + & - & - & + & + \\
\hline Growth in $2 \%(\mathrm{w} / \mathrm{v}) \mathrm{NaCl}$ & + & - & - & - & - \\
\hline Gelatinase (API 20E) & + & - & + & + & + \\
\hline \multicolumn{6}{|l|}{ Utilization of (Biolog GN3): } \\
\hline Dextrin & + & + & + & + & - \\
\hline Maltose & - & + & + & + & + \\
\hline Trehalose & - & - & + & + & - \\
\hline Cellobiose & - & - & + & + & - \\
\hline $\mathrm{N}$-Acetylneuraminic acid & + & - & - & - & - \\
\hline D-Fructose & - & + & + & + & + \\
\hline D-Galactose & - & + & + & + & - \\
\hline D-Fucose & + & + & - & + & - \\
\hline D-Sorbitol & - & - & - & + & + \\
\hline D-Mannitol & + & - & - & - & - \\
\hline D-Arabitol & + & - & + & + & - \\
\hline L-Alanine & + & - & + & + & + \\
\hline L-Arginine & - & - & - & + & - \\
\hline L-Aspartic acid & - & + & + & + & + \\
\hline L-Glutamic acid & - & + & + & + & + \\
\hline L-Pyroglutamic acid & - & + & - & - & + \\
\hline L-Serine & + & + & - & - & + \\
\hline D-Gluconic acid & + & + & - & + & + \\
\hline D-Glucuronic acid & - & + & + & - & - \\
\hline DNA G $+C$ content $(\mathrm{mol} \%)$ & 60.4 & 60 & 63.1 & $57-58$ & 65 \\
\hline
\end{tabular}

\section{Description of Hymenobacter yonginensis sp. nov.}

Hymenobacter yonginensis (yon.gi.nen'sis. N.L. masc. adj. yonginensis of or belonging to Yongin, Korea, from where the type strain was isolated).

Cells are Gram-staining-negative, non-motile, aerobic rods. Colonies on R2A are convex, circular and smooth with entire margins, reddish pink and approximately $5 \mathrm{~mm}$ in diameter after 2 days at $30{ }^{\circ} \mathrm{C}$. Good growth occurs on R2A, blood agar and TSA. No growth occurs on MA, DNA test agar or MacConkey agar. Growth occurs in the presence of $0-3.0 \%(\mathrm{w} / \mathrm{v}) \mathrm{NaCl}$ (optimum, $0.5 \%$ ), at $\mathrm{pH} 7-8$ (optimum, pH 7) and at $10-30{ }^{\circ} \mathrm{C}$ (optimum, $25{ }^{\circ} \mathrm{C}$ ). Oxidase and catalase activities are present. Arginine dihydrolase, lysine decarboxylase, ornithine decarboxylase, urease and tryptophan deaminase activities are absent. Casein and starch are hydrolysed. Citrate utilization, $\mathrm{H}_{2} \mathrm{~S}$ production, indole production and acetylmethylcarbinol production are not observed. Alkaline phosphatase, esterase (C4), esterase lipase (C8), leucine arylamidase, valine
Table 2. Cellular fatty acid compositions of strain HMD $1010^{\top}$ and closely related type strains

Strains: 1, HMD $1010^{\mathrm{T}}$; 2, H. aerophilus KACC $12071^{\mathrm{T}}$; 3, H. gelipurpurascens KACC $12069^{\mathrm{T}}$; 4, H. rigui KACC $11614^{\mathrm{T}}$; 5, H. psychrotolerans KACC $13767^{\mathrm{T}}$. Data were generated in this study; strains were grown on $\mathrm{R} 2 \mathrm{~A}$ at $25{ }^{\circ} \mathrm{C}$ for 2 days. Values are percentages of total fatty acids; only fatty acids amounting to at least $1.0 \%$ of the total in at least one strain are shown. tr, Trace $(<1 \%)$; ND, not detected.

\begin{tabular}{|c|c|c|c|c|c|}
\hline Fatty acid & 1 & 2 & 3 & 4 & 5 \\
\hline iso- $\mathrm{C}_{14: 0}$ & $\mathrm{ND}$ & $\operatorname{tr}$ & $\operatorname{tr}$ & 1.6 & $\operatorname{tr}$ \\
\hline iso- $\mathrm{C}_{15: 0}$ & 14.5 & 9.9 & 12.3 & 26.3 & 20.5 \\
\hline anteiso- $C_{15: 0}$ & 3.0 & 13.9 & 7.6 & 8.5 & 8.1 \\
\hline iso- $\mathrm{C}_{16: 1} \mathrm{H}$ & ND & 1.6 & 3.5 & $\mathrm{ND}$ & 2.0 \\
\hline iso- $\mathrm{C}_{16: 0}$ & 1.3 & $\operatorname{tr}$ & 2.7 & 1.1 & 1.5 \\
\hline $\mathrm{C}_{16: 1} \omega 5 c$ & 21.9 & 11.3 & 24.6 & 16.6 & 16.6 \\
\hline $\mathrm{C}_{16: 0}$ & 2.4 & 1.7 & 3.3 & 2.1 & 2.9 \\
\hline iso- $\mathrm{C}_{15: 0} 3-\mathrm{OH}$ & 5.3 & 2.0 & 3.6 & 5.2 & 2.9 \\
\hline anteiso- $\mathrm{C}_{17: 1} \omega 9 c$ & $\operatorname{tr}$ & 1.1 & $\operatorname{tr}$ & $\operatorname{tr}$ & $\operatorname{tr}$ \\
\hline iso- $\mathrm{C}_{17: 0}$ & 1.6 & 4.5 & 1.7 & 2.0 & 0.5 \\
\hline anteiso- $\mathrm{C}_{17: 0}$ & $\operatorname{tr}$ & 1.8 & 0.6 & 0.7 & 0.5 \\
\hline $\mathrm{C}_{16: 0} 3-\mathrm{OH}$ & 1.5 & $\operatorname{tr}$ & 1.5 & 1.0 & 1.3 \\
\hline iso- $\mathrm{C}_{17: 0} 3-\mathrm{OH}$ & 4.3 & 4.4 & 3.7 & 4.9 & 2.1 \\
\hline Summed feature $1^{\star}$ & 2.2 & $\operatorname{tr}$ & $\operatorname{tr}$ & 2.7 & 1.4 \\
\hline Summed feature $2^{\star}$ & 3.2 & $\operatorname{tr}$ & $\operatorname{tr}$ & 2.3 & $\operatorname{tr}$ \\
\hline Summed feature $3^{*}$ & 17.7 & 29.1 & 22.2 & 17.2 & 21.1 \\
\hline Summed feature $4^{*}$ & 11.9 & 12.2 & 5.2 & $\operatorname{tr}$ & 11.6 \\
\hline
\end{tabular}

${ }^{*}$ Summed features represent groups of two or three fatty acids that could not be separated using the MIDI system. Summed feature 1 comprised $\mathrm{C}_{13: 0} 3-\mathrm{OH}$ and/or iso- $\mathrm{C}_{15: 1} \mathrm{H}$, summed feature 2 comprised iso- $\mathrm{C}_{16: 1} \mathrm{I}$ and/or $\mathrm{C}_{14: 0} 3-\mathrm{OH}$, summed feature 3 comprised iso- $\mathrm{C}_{15: 0} 2-\mathrm{OH}$ and/or $\mathrm{C}_{16: 1} \omega 7 c$ and summed feature 4 comprised anteiso- $\mathrm{C}_{17: 1} \mathrm{~B}$ and/or iso- $\mathrm{C}_{17: 1} \mathrm{I}$.

arylamidase, cystine arylamidase, trypsin, acid phosphatase, naphthol-AS-BI-phosphohydrolase, $\alpha$-glucosidase and $N$ acetyl- $\beta$-glucosaminidase activities are present, but lipase (C14), $\alpha$-chymotrypsin, $\alpha$-galactosidase, $\beta$-galactosidase, $\beta$ glucuronidase, $\beta$-glucosidase, $\alpha$-mannosidase and $\alpha$-fucosidase activities are absent. The following Biolog GN3 microplate compounds are utilized: dextrin, sucrose, lactose, melibiose, $N$-acetyl- $\beta$-D-mannosamine, $N$-acetylneuraminic acid, D-mannose, D- and L-fucose, L-rhamnose, D- and L-serine, D-mannitol, D-arabitol, D-glucose 6-phosphate, D-fructose 6-phosphate, D-aspartic acid, gelatin, glycyl L-proline, L-alanine, pectin, D-galacturonic acid, L-galactonic acid lactone, D-gluconic acid, glucuronamide, methyl pyruvate, L-lactic acid, $\alpha$-ketoglutaric acid, L-malic acid, bromosuccinic acid, Tween 40 , aminobutyric acid, $\beta$-hydroxy-DLbutyric acid, propionic acid, acetic acid and formic acid. The following carbon sources are not utilized: maltose, trehalose, cellobiose, gentiobiose, turanose, stachyose, raffinose, methyl $\beta$-D-glucoside, D-salicin, $\mathrm{N}$-acetyl-D-glucosamine, $\mathrm{N}$-acetylD-galactosamine, $\alpha$-D-glucose, D-fructose, D-galactose, 3 methyl glucose, inosine, D-sorbitol, myo-inositol, glycerol, 
L-arginine, L-aspartic acid, L-glutamic acid, L-histidine, Lpyroglutamic acid, D-glucuronic acid, mucic acid, quinic acid, D-saccharic acid, $p$-hydroxyphenylacetic acid, D-lactic acid methyl ester, citric acid, D-malic acid, $\alpha$-hydroxybutyric acid, $\alpha$-ketobutyric acid and acetoacetic acid. The major fatty acids are $\mathrm{C}_{16: 1} \omega 5 c$, summed feature 3 (iso- $\mathrm{C}_{15: 0} 2-\mathrm{OH}$ and/or $\mathrm{C}_{16: 1} \omega 7 c$ ), iso- $\mathrm{C}_{15: 0}$ and summed feature 4 (anteiso- $\mathrm{C}_{17: 1} \mathrm{~B}$ and/or iso- $\left.\mathrm{C}_{17: 1} \mathrm{I}\right)$. The complete fatty acid profile of the type strain is given in Table 2 . The DNA G $+\mathrm{C}$ content of the type strain is $60.4 \mathrm{~mol} \%$.

The type strain, HMD $1010^{\mathrm{T}}$ (=KCTC $22745^{\mathrm{T}}=\mathrm{CECT}$ $7546^{\mathrm{T}}$ ), was isolated from a mesotrophic freshwater pond in Yongin, Republic of Korea.

\section{Acknowledgements}

This research was supported by the project on survey and excavation of Korean indigenous species of the National Institute of Biological Resources (NIBR) under the Ministry of Environment, Korea.

\section{References}

Baik, K. S., Seong, C. N., Moon, E. Y., Park, Y. D., Yi, H. \& Chun, J. (2006). Hymenobacter rigui sp. nov., isolated from wetland freshwater. Int J Syst Evol Microbiol 56, 2189-2192.

Bernardet, J. F., Vancanneyt, M., Matte-Tailliez, O., Grisez, L., Tailliez, P., Bizet, C., Nowakowski, M., Kerouault, B. \& Swings, J. (2005). Polyphasic study of Chryseobacterium strains isolated from diseased aquatic animals. Syst Appl Microbiol 28, 640-660.

Buczolits, S., Denner, E. B., Vybiral, D., Wieser, M., Kämpfer, P. \& Busse, H.-J. (2002). Classification of three airborne bacteria and proposal of Hymenobacter aerophilus sp. nov. Int J Syst Evol Microbiol 52, 445-456.

Buczolits, S., Denner, E. B., Kämpfer, P. \& Busse, H.-J. (2006). Proposal of Hymenobacter norwichensis sp. nov., classification of 'Taxeobacter ocellatus', 'Taxeobacter gelupurpurascens' and 'Taxeobacter chitinovorans' as Hymenobacter ocellatus sp. nov., Hymenobacter gelipurpurascens sp. nov. and Hymenobacter chitinivorans sp. nov., respectively, and emended description of the genus Hymenobacter Hirsch et al. 1999. Int J Syst Evol Microbiol 56, 2071-2078.

Cho, J. C. \& Giovannoni, S. J. (2003). Parvularcula bermudensis gen. nov., sp. nov., a marine bacterium that forms a deep branch in the $\alpha$ Proteobacteria. Int J Syst Evol Microbiol 53, 1031-1036.

Chun, J., Lee, J. H., Jung, Y., Kim, M., Kim, S., Kim, B. K. \& Lim, Y. W. (2007). EzTaxon: a web-based tool for the identification of prokaryotes based on 16S ribosomal RNA gene sequences. Int J Syst Evol Microbiol 57, 2259-2261.

Collins, M. D., Hutson, R. A., Grant, I. R. \& Patterson, M. F. (2000). Phylogenetic characterization of a novel radiation-resistant bacterium from irradiated pork: description of Hymenobacter actinosclerus sp. nov. Int J Syst Evol Microbiol 50, 731-734.

Felsenstein, J. (1981). Evolutionary trees from DNA sequences: a maximum likelihood approach. J Mol Evol 17, 368-376.

Felsenstein, J. (1985). Confidence limits on phylogenies: an approach using the bootstrap. Evolution 39, 783-791.

Fitch, W. M. (1971). Toward defining the course of evolution: minimum change for a specific tree topology. Syst Zool 20, 406416.

Hirsch, P., Ludwig, W., Hethke, C., Sittig, M., Hoffmann, B. \& Gallikowski, C. A. (1998). Hymenobacter roseosalivarius gen. nov., sp. nov. from continental Antarctic soils and sandstone: bacteria of the Cytophaga/Flavobacterium/Bacteroides line of phylogenetic descent. Syst Appl Microbiol 21, 374-383.

Kim, K. H., Im, W. T. \& Lee, S. T. (2008). Hymenobacter soli sp. nov., isolated from grass soil. Int J Syst Evol Microbiol 58, 941-945.

MacFaddin, J. F. (1980). Biochemical Tests for Identification of Medical Bacteria, 2nd edn. Baltimore: Williams \& Wilkins.

Mesbah, M. \& Whitman, W. B. (1989). Measurement of deoxyguanosine/thymidine ratios in complex mixtures by high-performance liquid chromatography for determination of the mole percentage guanine + cytosine of DNA. J Chromatogr A 479, 297-306.

Saitou, N. \& Nei, M. (1987). The neighbor-joining method: a new method for reconstructing phylogenetic trees. Mol Biol Evol 4, 406-425.

Tamura, K., Dudley, J., Nei, M. \& Kumar, S. (2007). MEGA4: molecular evolutionary genetics analysis (MEGA) software version 4.0. Mol Biol Evol 24, 1596-1599.

Wayne, L. G., Brenner, D. J., Colwell, R. R., Grimont, P. A. D., Kandler, O., Krichevsky, M. I., Moore, L. H., Moore, W. E. C., Murray, R. G. E. \& other authors (1987). International Committee on Systematic Bacteriology. Report of the ad hoc committee on reconciliation of approaches to bacterial systematics. Int J Syst Bacteriol 37, 463-464.

Xu, J. L., Liu, Q. M., Yu, H. S., Jin, F. X., Lee, S. T. \& Im, W. T. (2009). Hymenobacter daecheongensis sp. nov., isolated from stream sediment. Int J Syst Evol Microbiol 59, 1183-1187.

Zhang, Q., Liu, C., Tang, Y., Zhou, G., Shen, P., Fang, C. \& Yokota, A. (2007). Hymenobacter xinjiangensis sp. nov., a radiation-resistant bacterium isolated from the desert of Xinjiang, China. Int J Syst Evol Microbiol 57, 1752-1756.

Zhang, G., Niu, F., Busse, H.-J., Ma, X., Liu, W., Dong, M., Feng, H., An, L. \& Cheng, G. (2008). Hymenobacter psychrotolerans sp. nov., isolated from the Qinghai-Tibet Plateau permafrost region. Int J Syst Evol Microbiol 58, 1215-1220.

Zhang, L., Dai, J., Tang, Y., Luo, X., Wang, Y., An, H., Fang, C. \& Zhang, C. (2009). Hymenobacter deserti sp. nov., isolated from the desert of Xinjiang, China. Int J Syst Evol Microbiol 59, 77-82.

Zhang, D. C., Busse, H.-J., Liu, H. C., Zhou, Y. G., Schinner, F. \& Margesin, R. (2011). Hymenobacter psychrophilus sp. nov., a psychrophilic bacterium isolated from soil. Int J Syst Evol Microbiol 61, 859-863. 